$\mathrm{Oz}$

$1-1-2015$

\title{
The Deep Section: Karst Urbanism in Town Branch Commons
}

Kate Orff

SCAPE/Landscape Architecture

Geni Wirth

SCAPE/Landscape Architecture

Anne Weber

SCAPE/Landscape Architecture

Follow this and additional works at: https://newprairiepress.org/oz

Part of the Architecture Commons

(c) (i) $(9)$

This work is licensed under a Creative Commons Attribution-Noncommercial-No Derivative Works 4.0 License.

\section{Recommended Citation}

Orff, Kate; Wirth, Geni; and Weber, Anne (2015) "The Deep Section: Karst Urbanism in Town Branch Commons," Oz: Vol. 37. https://doi.org/10.4148/2378-5853.1547

This Article is brought to you for free and open access by New Prairie Press. It has been accepted for inclusion in Oz by an authorized administrator of New Prairie Press. For more information, please contact cads@k-state.edu. 


\title{
The Deep Section
}

\section{Karst Urbanism in Town Branch Commons}

\author{
Kate Orff, Gena Wirth, and Anne Weber \\ SCAPE/Landscape Architecture
}

Nothing is without context. Every lawn, parking lot, skyscraper, or national park has been shaped by a myriad of factors natural and humanmade. As a research-driven practice, our work at SCAPE is empowered by the complex layers of systems that act upon a site: rates of urban development, economic shifts, ecological flows of plants and animals, hydrological systems, and circulation systems, to name just a few. We see design as a means not only to reveal these system-to make their traces legible-but also as an opportunity to act within and upon them. Our work on Town Branch Commons, an urban plan for the heart of the Bluegrass in Lexington, Kentucky, looks not only at how natural systems can be harnessed to reshape urban growth, but how social agency and public engagement can help transform citizens' relationship with water.

In Kentucky, context is defined not only by the many forces that have shaped its surface-its rich history, diverse ecologies, rural/urban boundaries, and networked infrastructuresbut also by what lies beneath. Karst geology is Lexington's hidden secret. The unique limestone layer underlying the city nourishes the growth of Kentucky Bluegrass and is rumored to improve the taste of Lexington's locally distilled bourbon. The porous qualities of Karst create unexpected patterns of water flow, where underground waterways travel through permeable limestone layers to surface into pools, disappear into sinks, and dramati-

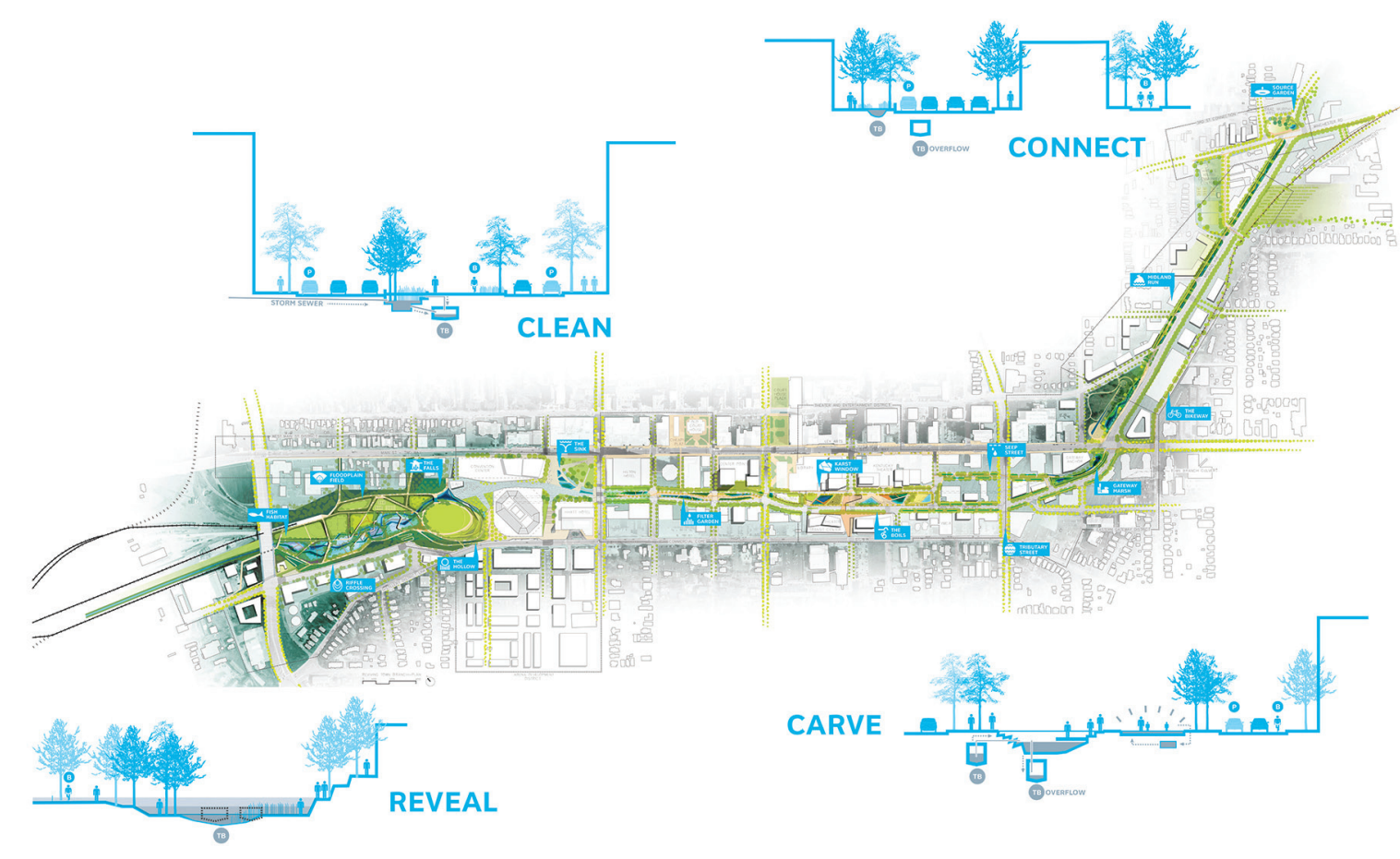

Harnessing its deeply local context to shape the identity of the downtown area, Town Branch Commons offers a future for Lexington that is inclusive, resilient, competitive, and ecologically productive.

\section{Strategy}

Inspired by the unique flow patterns of Karst, our design strategy-Reveal, Clean, Carve, Connect-ties the nuances of Lexington's rich substrata to unique development potentials on its surface. We aim to reveal the underground stream and the multi-faceted qualities of water as a series of urban destinations, clean Town Branch into an ecologically viable and safe waterway, carve Town Branch into the downtown fabric to stage its topographic qualities, and connect Town Branch back into the neighborhoods where it originates. Rather than a single, linear stream channel, Town Branch becomes a network of water windows, pools, pockets, fountains, and filter gardens that evoke and expose the underground stream and shape diverse typologies of public space along its length. Town Branch historically gave form to Lexington's early settlement pattern and it can once again catalyze and unite the city along its newly formed banks.

\section{Karst Geology as Placemaker}

The geology of the Karst landscape and the emergent patterns of use downtown have provided a framework that adapts to a diversity of urban conditions along its length. In the natural hills and valleys around Lexington, water surfaces into pools, then disappears into "sinks" to travel underground and unexpectedly "boil" back up to the surface. The idea that Town Branch can surface and disappear again within the city fabric not only makes for a more feasible design, but it sparks difference and generates new places along its length that are deeply site specific 


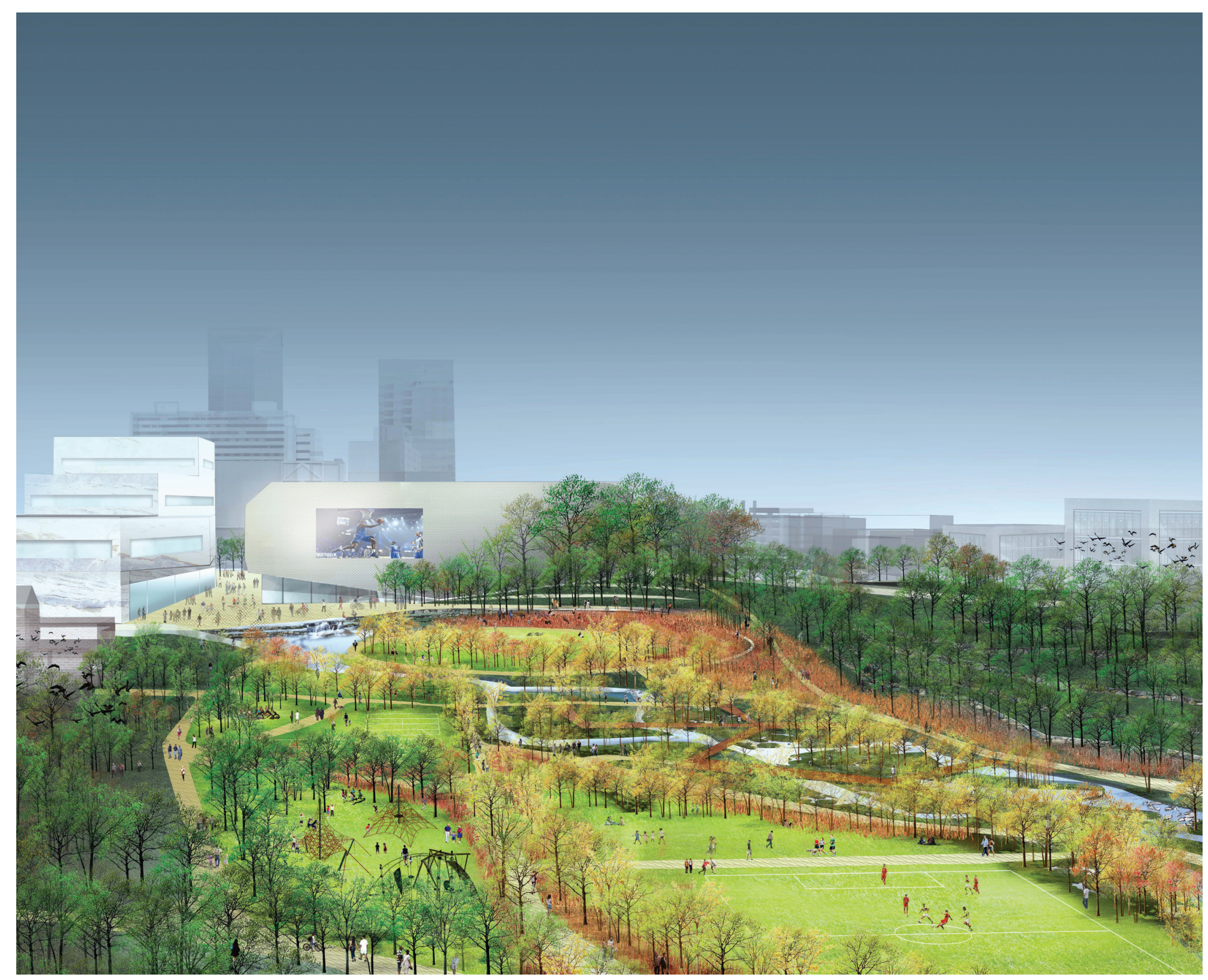



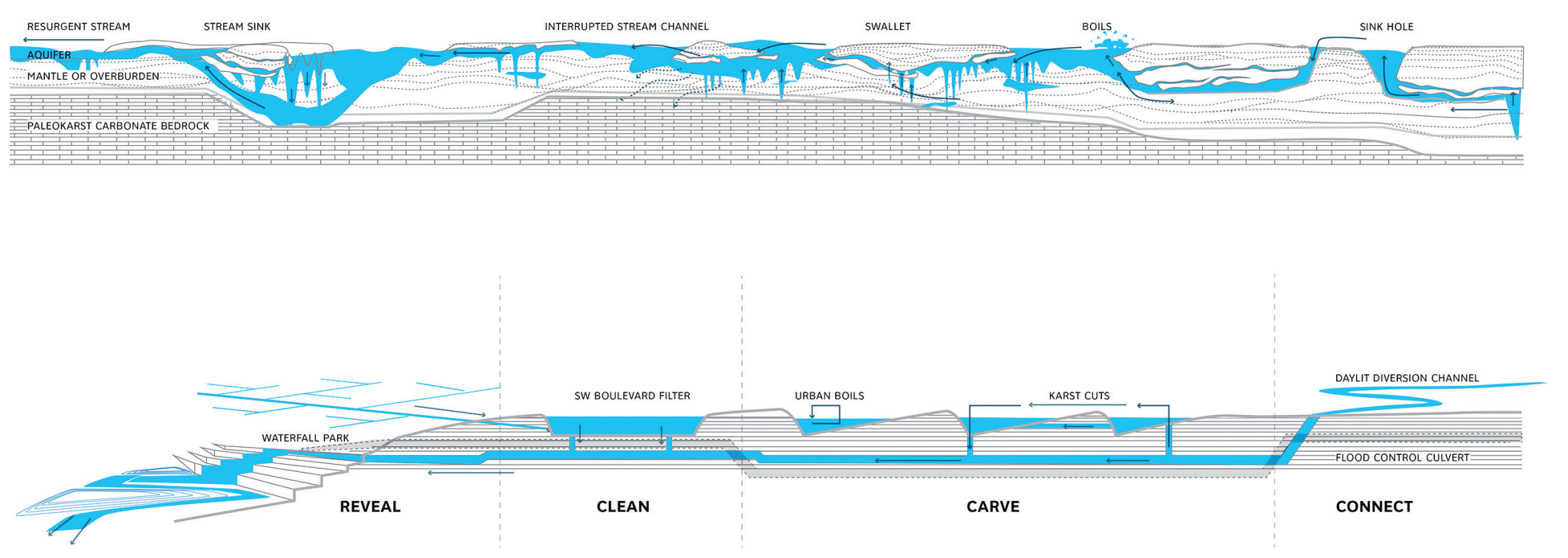

and that magnify the existing urban districts that have emerged organically. Karst landscapes and their complex hydrology are the foundation of Lexington's regional landscape, and are well suited in form and function to urban place-making and adaptable to the complex conditions of the urban underground. Vine Street in its current form is a linear infrastructural barrier that divides the city. Rather than creating additional linear barriers, we propose to use the pockets, pools,
Karst landscapes to re-shape the street, activating open space in the heart of the city. Rather than recreating a singular pre-colonial ecology, the project revives Town Branch as a series of diverse and resilient ecosystems local in character yet responsive to the needs of a twentyfirst century city.

\section{Landscape Infrastructure}

Historically a waste canal, sewer, and water conduit for the city, Town Branch is a neglected, hidden, and under-utilized fragment of public infrastructure. Town Branch Commons seeks to catalyze the redesign of other single-use infrastructures in downtown Lexington, introducing the public realm as a critical element within the city's traffic and water distribution networks. Vine Street is currently a one-way vehicular thoroughfare with sparse pedestrian presence, its oversized lanes increasing traffic speeds and limiting safe pedestrian access across. While a rural bike network of the Bluegrass region is well established, the urban bike and pedestrian routes are often disjointed.
By reclaiming space from oversized lanes and routing a cycle track and pedestrian paths along Vine Street, the Town Branch Commons will also act as a missing link in urban, suburban, rural and regional trail networks for bikers as well as pedestrians. This new transportation infrastructure will allow the rising number of bicycle commuters to reach their work place more safely and quickly, while also providing recreational loops for families and sport enthusiasts. While making room for alternative modes of transportation, the redesigned 
GEOLOGIC RESOURCES

OF KENTUCKY

1. Jackson Purchas

2. Mississippi Plateaus

3. Western Coal Fields

4. Outer Bluegrass

5. Inner Bluegrass

Quarry
High potential for karst development

Moderate potential for karst development
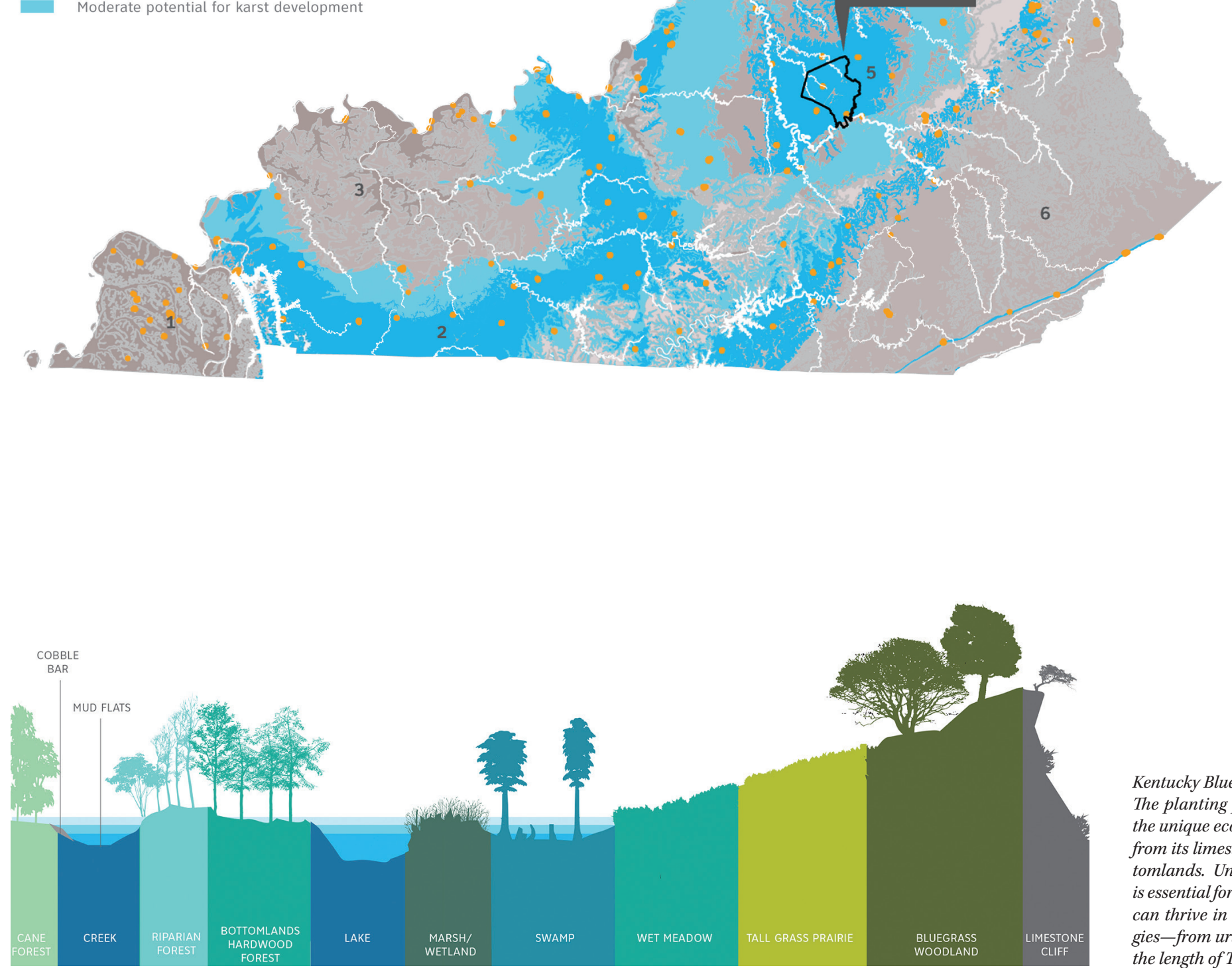

Kentucky Bluegrass Ecologies:

The planting palette draws inspiration from

the unique ecological context of the Bluegrass, from its limestone bluffs to the hardwood bot-

tomlands. Understanding a range of ecotypes is essential for finding native plant species that can thrive in the range of novel urban ecologies-from urban plaza to daylit park-along the length of Town Branch Commons. 


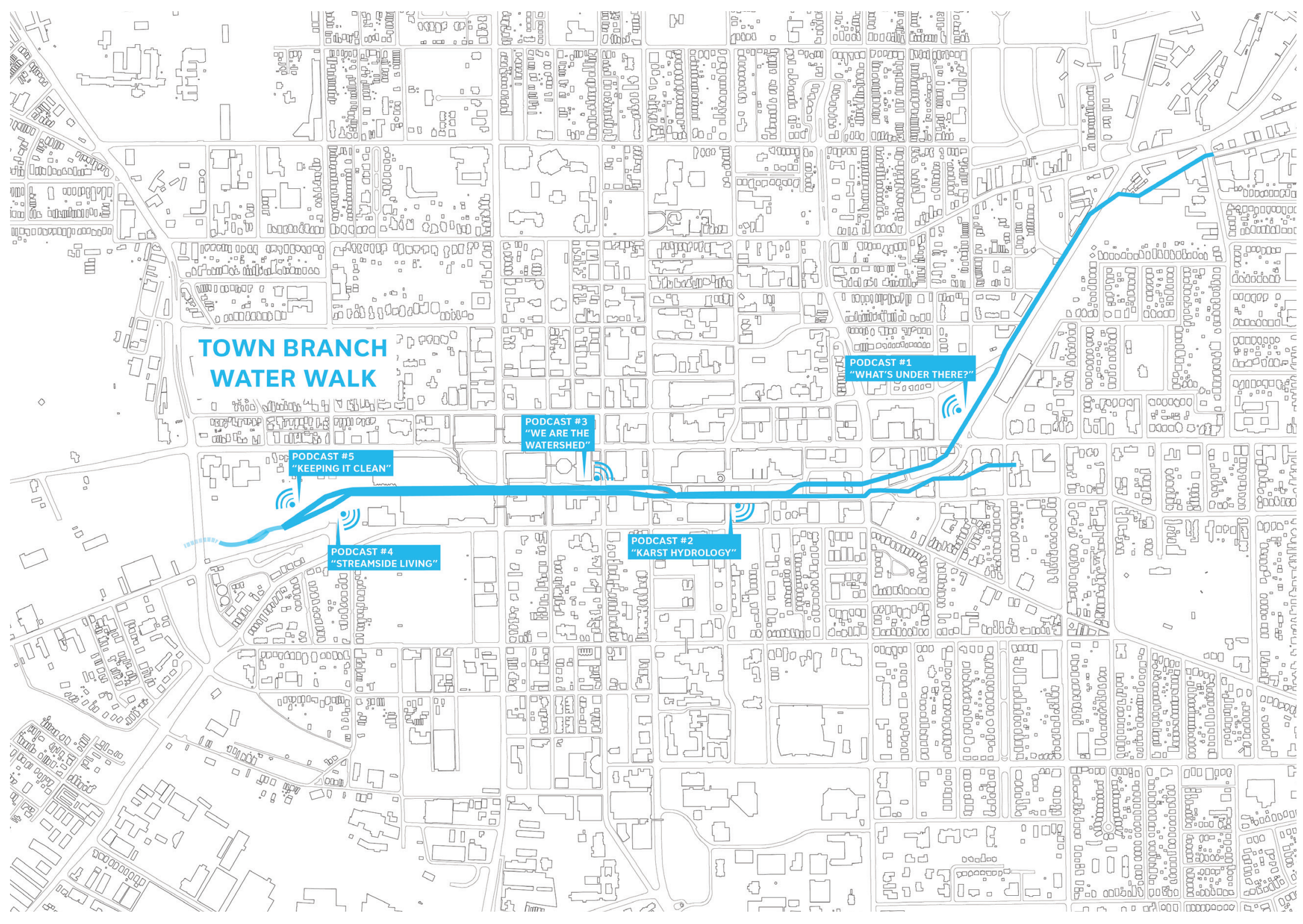




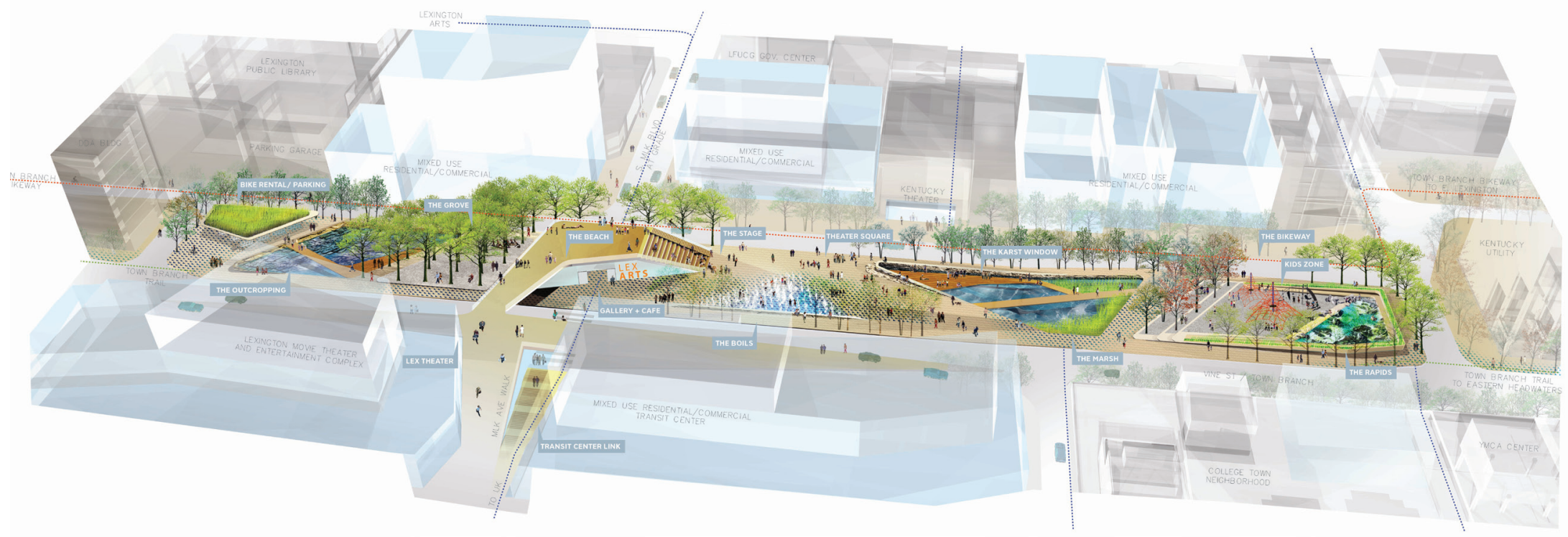

Vine Street and Midland Avenue also creates spaces to filter Town Branch waters along its spine.

The waters of Town Branch offer further opportunity to remake Lexington's public realm. Originating in the streets and sidewalks of the city, Town Branch water will be collected in a small pools along the stream path and filtered by vegetation, boosting the water volume of the small stream, removing urban contaminants that degrade downstream ecologies, and shaping a series of responsive public spaces. At the watershed scale, we are currently collaborating with a diverse group of partners (including the Lexington-Fayette County Government, Town Branch Trail Association, and the University of Kentucky among others) to produce the Town Branch Water Walk-a self-guided podcast tour of downtown Lexington's hidden water body. Lexington citizens who have long forgotten the underground stream will be reminded that the waters (and fate) of Town Branch exists in their backyards. Through engaging the public, the Water Walk will reframe urban water as restorative, healthy, and valued.

\section{Project Framework}

Lexington has many enviable urban features-a vigorous economy, a dynamic Main Street, a vibrant and internationally-celebrated local culture, strong academic institutions, and diverse residential neighborhoods within walking distance of downtown. Reviving Town Branch links these successes through the formation of a legible public space network that offers new ways to live, work, and play within the city. The spatial operations of "reveal, clean, carve, connect" define how Town Branch is interpreted at the urban surface and organize it into four memorable landscape zones: Lexington Hollows, Downtown Greenway, Karst Commons, and Eastern Headwaters. This spatial sequence brings together a distinct 'revealed' form of the water together with a specific urban context, giving form and identity to future development initiatives.

\section{REVEAL/Lexington Hollows}

Recreation, urban development, and river ecology unite at Lexington Hollows. Placed at the nexus of three emerging development zones, the 
WHERE IS TOWN BRANCH? The urban streampath is marked by a palette of materials adapted from karst geology and hydrology.

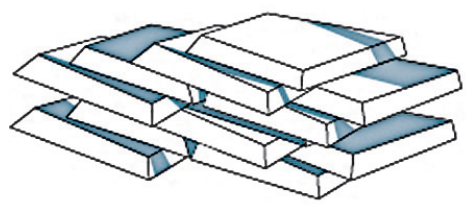

STONE FENCE Lexington's Bluegrass Country is marked by karst outcroppings desinged to reflects the striated form and porous qualities of karst limestone. Surface runoff filters through and recharges Town Branch at strategic zones.

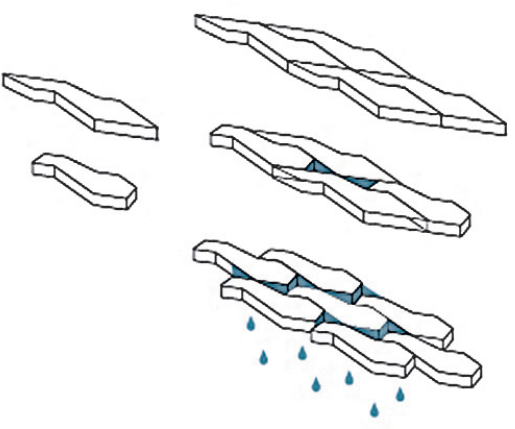

Wildcat fans, convention goers, and the public alike can collect on the event terrace and soft lawn amphitheater of the Hollows to watch projected highlights of the basketball games, and on non-game weekends, evening movies with family and friends. Looking west, with the Jefferson Street overpass removed, an expansive view is revealed of the sinuous path of Town Branch as it unfolds towards the trailhead of Town Branch Trail and Bluegrass Country beyond. Descending into the Hollows along the curving amphitheater path, spaces for birdwatchers, children, soccer players, and youth basketball practice unfold within the scrim of riparian trees that line the brook's edge. Recreational and habitat rooms protect adjacent development from flood risk while

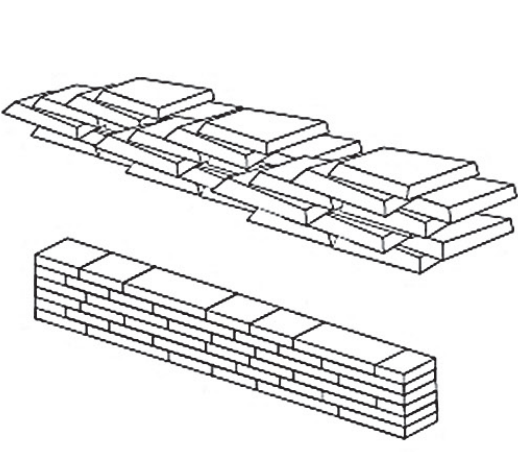
Cownestone walls. Downtown, the stone fence separates traffic, retains water, and provides seating.

serving the recreational needs of the city. Old culvert infrastructure is recast as public space and integrated into the heart of the stream channel as bridge crossings and overlooks. Lexington Hollows showcases the region's ecology alongside its renowned athletics, creating a green heart within the city.

Whether Town Branch water is revealed or remains underground, its path is clearly marked as it weaves in and out of the city's fabric. Paving, planting, and structural elements form a material palette that evokes the underground stream. A linear paver is developed with varying degrees of porosity that reflects the porous qualities of Karst limestone while allowing water to infiltrate into the stream channel below.
RIPARIAN FOREST Streambank vegetation replaces traditional street tree planting, enhancing ecological diversity and evoking the path of Town Branch.

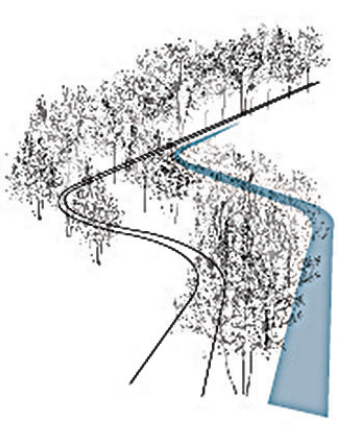

Flood-tolerant trees are planted in thin hedgerows to evoke the feel of a riparian forest edge, while remaining tolerant to the low-oxygen conditions of the urban streetscape. Stone fences, prominent in the rural Bluegrass Country, are extended downtown and provide places to sit and lounge while protecting pedestrians from vehicular traffic.

Our plan's approach to materials enlivens and synthesizes the landscape of Vine street along its length, culminating in a central plaza at Rupp Arena and the Falls through not only physical connection and landscape spaces, but by integrating night-time lighting and dynamic projections on the "Hollows" side of Rupp, promoting a greater sense of security, more feet-on-the-street during evening 


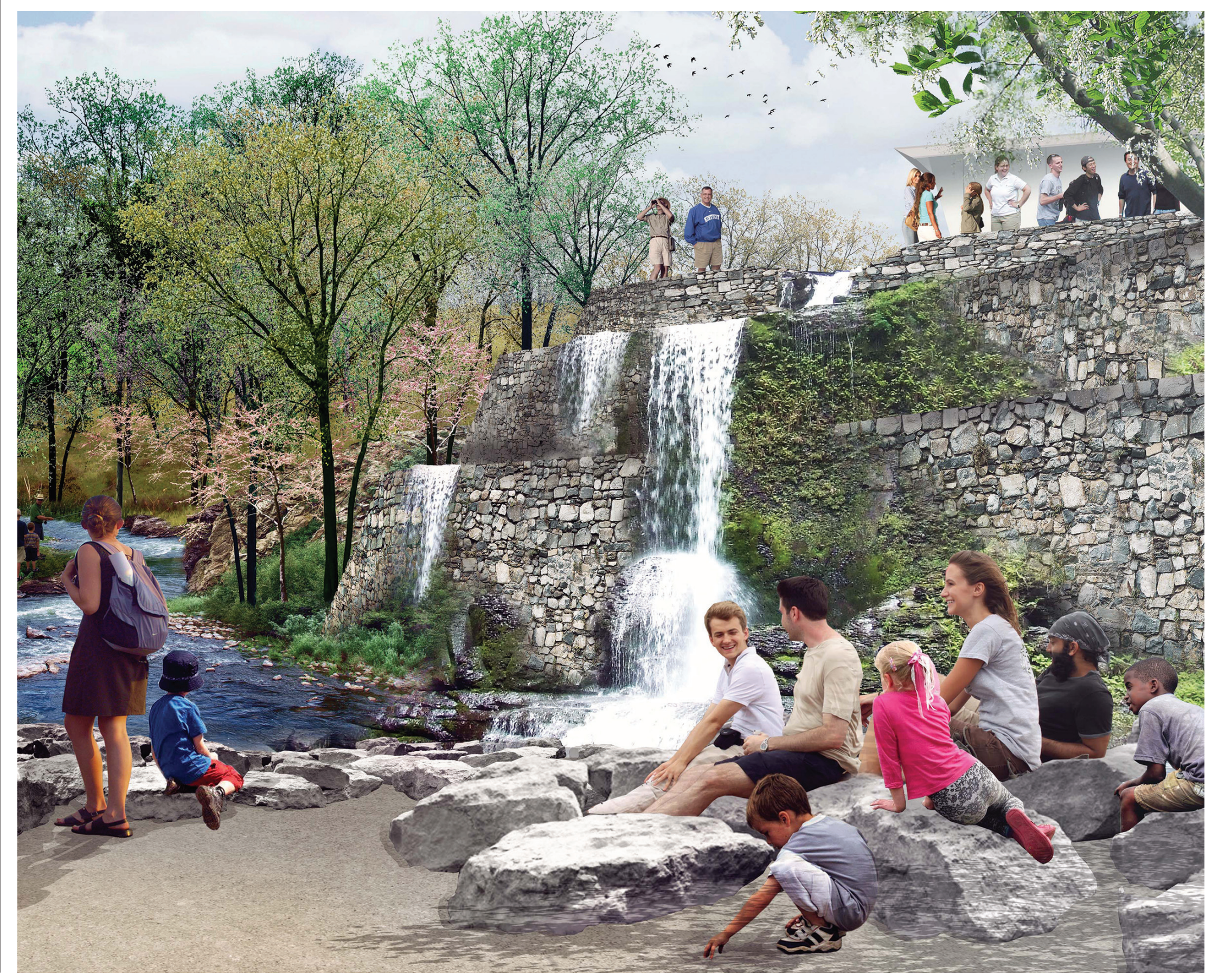


hours, and ultimately increased economic activity and vitality. An investment in the design and materiality of Town Branch will unlock value along its edges.

\section{CLEAN/Downtown Greenway}

Re-envisioned as a multi-modal corridor, Vine Street's Downtown Greenway is designed as a sinuous respite for weekday workers out for a break, morning joggers, commuting cyclists, and those strolling after a meal on Main Street. Town Branch is re-cast as hybrid hydrological and urban infrastructure, creating defined and safe spaces for water, pedestrians, bicyclists, and vehicles along its path. The water's path is marked with a series of linear filtration gardens shaped to create pockets of slow space within the promenade and protect walkers and bicyclists from surrounding vehicular traffic. The city cleans Town Branch, as the greenway gardens collect, filter, and slow significant amounts of stormwater runoff collected upstream before it reaches the stream channel. Greater numbers of pedestrians will move through the downtown district during longer periods of the day and evening, which translates into increased economic activity, more profitable businesses, and, over time, higher-achievable rents and higher property values.

\section{CARVE/Karst Commons}

New water-based public spaces are strategically carved into Lexington's emerging arts and entertainment district, catalyzing development of vacant sites downtown and expanding amenities for urban living. Renovation of the MLK Boulevard overpass as a pedestrian way creates a layered, common space that attracts activity from surrounding streets and refocuses existing theater, arts, and entertainment programs around a central urban plaza and "stage." The design of this zone, in particular, accommodates opportunities to imbed revenue-generating concessions like a café or bike rental shop that can vary by season, time of day, special event, and location. Spatially, Town Branch emerges, disappears, and re-emerges as Karst cuts and designed rock formations, creating larger windows for dynamic play, performance, and entertainment while orienting one to the underground stream below. Outdoor spaces are programmed by established and emerging cultural venues, as Karst Commons is a destination for those looking to browse the LexArts pop-up gallery, swing dance groups taking advantage of the open space and audience, and Kentucky Theater-lovers looking to linger after an evening performance, extending activity to longer periods of the day and evening. Water windows shape multifunctional spaces for relaxation and entertainment throughout the day, whether to park a bicycle and grab a morning coffee, meet up for a game of chess before catching the bus home, or take the kids out for a Saturday afternoon fountain frolic at The Boils. Our signature paving pattern-more permeable in planted and water based zones-stretches across and compresses to support active movement, linking the Commons to the more linear boulevard at the Downtown Greenway.

\section{CONNECT/Eastern Headwaters}

Rather than being fed by a single source, Town Branch waters come

Karst Commons is a key common area in Town Branch Commons. Ammenities include a cen tral urban plaza and "stage." Outdoor spaces are programmed by established and emerging cultural venues.

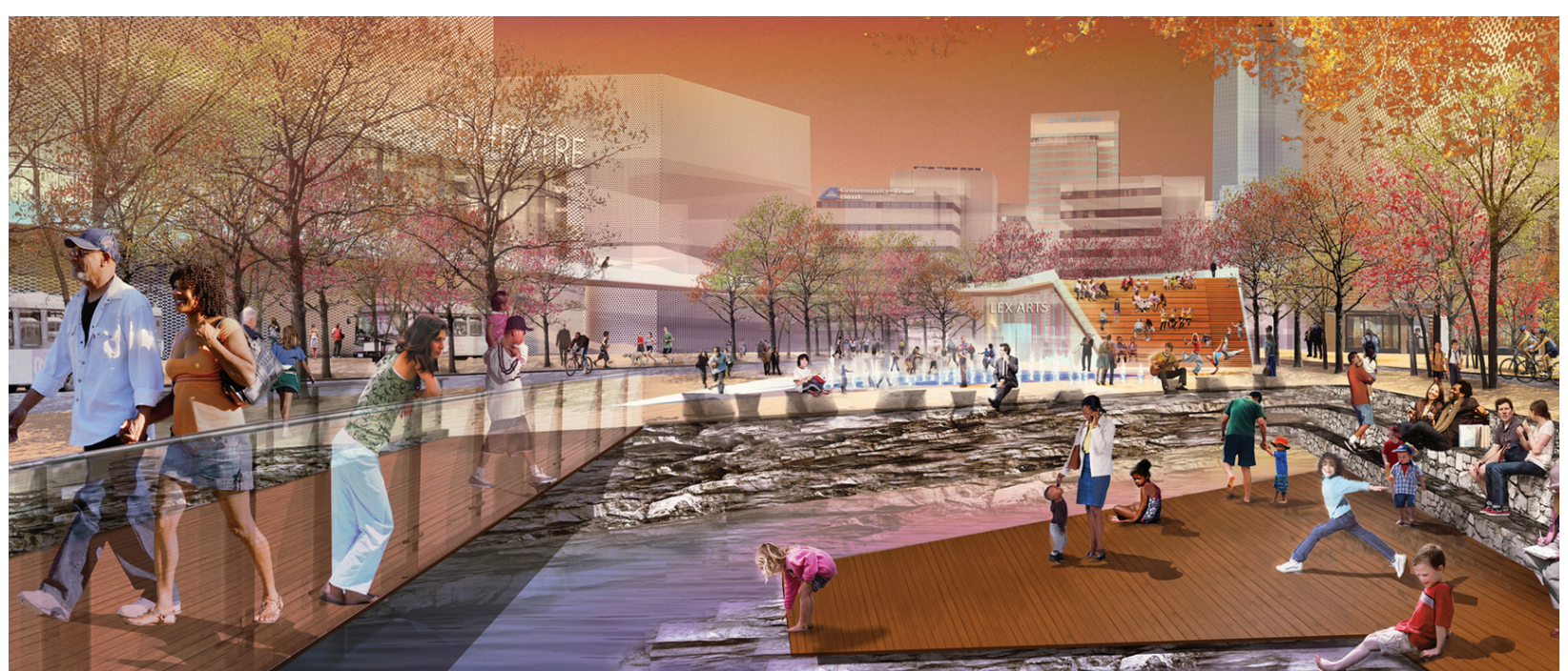




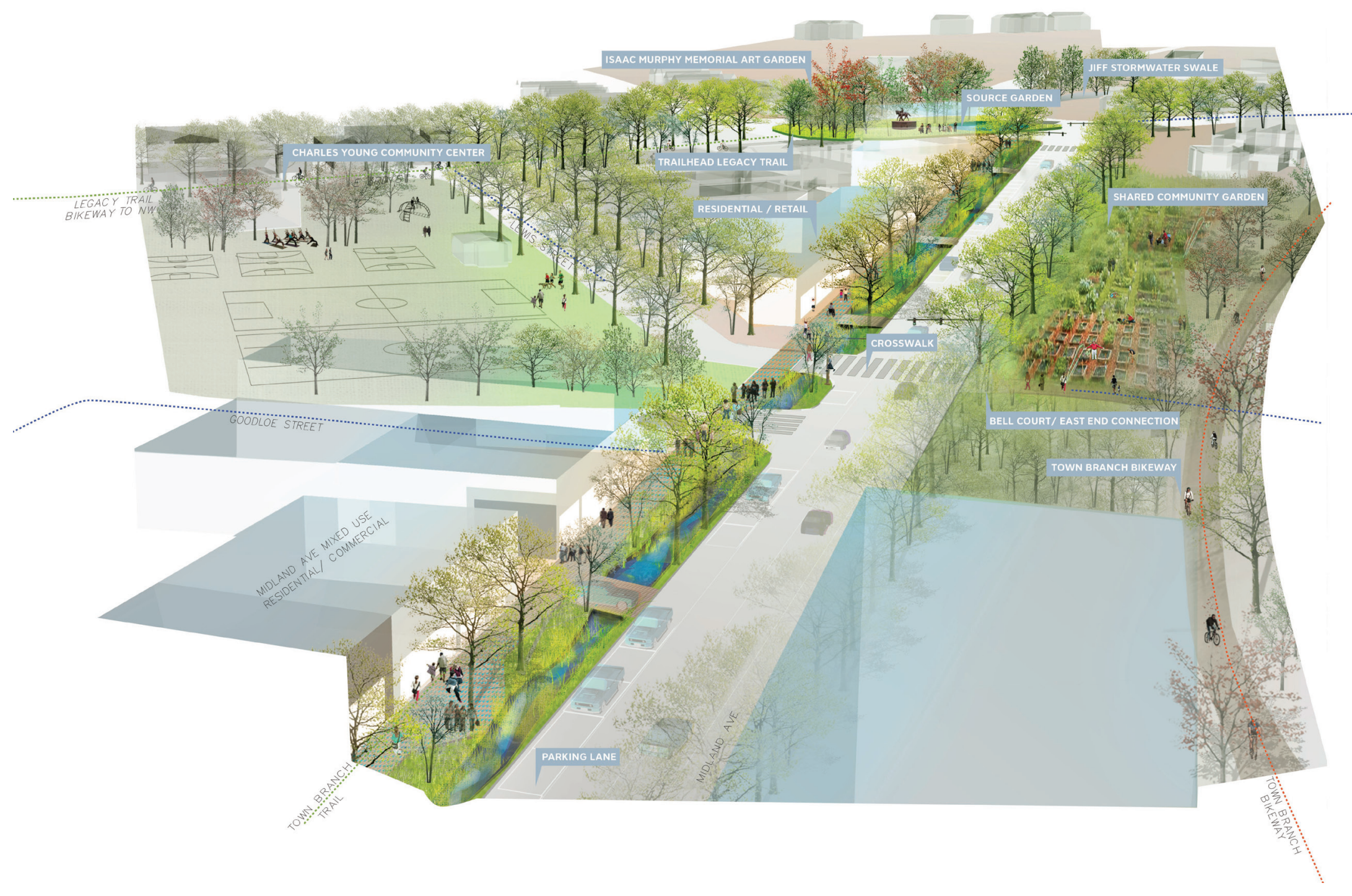

from a broad field of neighborhoods in Lexington's northeast. Likewise, the Eastern Headwaters branches out to actively bring people from headwater neighborhoods towards the stream path and towards each other. Currently divided by rail and highway infrastructure, the revealed Town Branch provides a connective riparian tissue that links these diverse communities along a revitalized neighborhood corridor. New low-rise, mixed-use development integrates into the existing residential fabric adjacent to Midland Avenue, reconfigured as a blue street, with parking lanes, a thick riparian buffer, protective stone fence, and the trickling path of Town Branch. East End and Bell Court residents benefit from Midland as a neighborhood destination, whether to pick up some produce at the headwaters community garden, take a walk downtown, or cross over to the Charles Young recreational fields for a game of pickup football. The divisive street becomes a connective bikeway, linking headwater residents across Midland Avenue, into downtown, and to the broader region along the Third Street Legacy Trail extension. The Isaac Murphy Memorial Arts Garden becomes the gateway to Town Branch, drawing curious tourists eager to learn about the history of the city and adventurous cyclists determined to complete the Legacy Trail.

From its geologic inspiration to future social connections, our vision is inclusive, and the headwaters reach out to build upon the planning and design initiatives of Lexington's underserved neighborhoods and constituents.
More on Town Branch Commons and the Fall 2015 launch of the Town Branch Water Walk podcast tour can be found at SCAPE's website (http://www.scapestudio.com/) and the Town Branch Commons website (http://www.townbranchcommons.com/). 